\title{
IMMUNOLOGIC ASPECTS OF WEST SYNDROME AND EVIDENCE OF PLASMA INHIBITORY EFFECTS ON T CELL FUNCTION
}

\author{
Terezinha C.B. Montelli ${ }^{1}$, Angela M.V.C. Soares², Maria Terezinha S. Peraçoli
}

\begin{abstract}
Study objective: The purpose of this study was to assess the extent of immune dysfunction in a well-defined group of epileptic patients: children with diagnosis of West syndrome (WS) or with transitions to another age-related EEG patterns, the multifocal independent spikes (MIS), and the slow spike-wave complexes (Lennox-Gastaut syndrome - LGS). Thus, WS was studied at different points of the natural evolutive history of the disease. Method: A group of 50 patients (33 with WS, 10 with LGS and 7 with MIS) and 20 age-matched healthy controls were submitted to enumeration of T lymphocyte subsets: CD1, CD3, CD4, CD8, CD4/CD8 ratio and lymphocyte proliferation assay to phytohaemagglutinin (PHA), in the presence of autologous and $A B$, homologous plasma. Dinitrochlorobenzene (DNCB) skin test sensitization was performed only in patients. Determinations of $\lg G, \lg A$, and $\lg M$ serum levels were compared to standard values for Brazilian population in different age ranges. Results: Sensitization to DNCB showed absent or low skin reactions in $76 \%$ of the patients. High levels of $\lg G(45.7 \%)$ and $\lg \mathrm{M}(61.4 \%)$, and lower levels of $\lg A(23.9 \%)$ were detected in the serum of the patients. Enumeration of lymphocyte subsets in peripheral blood showed: low $C D 3+(p<0.05)$, low CD4+ $(p<0.05)$, high $C D 8+(p<0.01)$ and low $C D 4+/ C D 8+$ ratio $(p<0.001)$. The proportion of $C D 1+$ cells in the control group was less than 3\%, while ranged between 6 and $11 \%$ in $18 \%$ of the patients. The in vitro PHA-induced T cell proliferation showed significantly low blastogenic indices only when patients cells were cultured in presence of their own plasma. No differences in blastogenic indices were observed when the cells of patients and controls were cultured with human AB plasma. Conclusion: The immunodeficiency in WS was mainly characterized by anergy, impaired cell-mediated immunity, altered levels of immunoglobulins, presence of immature thymocytes in peripheral blood and functional impairment of T lymphocytes induced by plasma inhibitory factors.
\end{abstract}

KEY WORDS: dinitrochlorobenzene, West syndrome, Lennox-Gastaut syndrome, multifocal-independent spike syndrome, T-lymphocytes subsets, immunoglobulins, proliferation assay, T cells, CD1, CD3, CD4, CD8.

\begin{abstract}
Aspectos imunológicos da síndrome de West e evidência de efeitos inibitórios do plasma sobre a função de células T

RESUMO - Objetivo: 0 objetivo deste estudo foi determinar o perfil da deficiência imune em um grupo bem definido de epilepsia: crianças com síndrome de West (SW) e seus padrões EEG de evolução, idade-dependentes, como os complexos onda-aguda- onda lenta generalizadas da síndrome de Lenox-Gastaut (SLG) e as pontas multifocais independentes (PMI). Método: Um grupo de 50 crianças, 33 com SW, 10 com SLG, 7 com PMI e 20 crianças sadias (controle) foram avaliadas em relação aos seguintes parâmetros:determinação de subpopulações de linfócitos $T(C D 1, C D 3, C D 4$ e $C D 8)$, relação $C D 4 / C D 8$ e resposta proliferativa de linfócitos frente a fitohemaglutinina (PHA), na presença de plasma autólogo ou de plasma $A B$ (homólogo). A prova cutânea de sensibilização ao Dinitroclorobenzeno (DNCB) foi realizada apenas nos pacientes. Os níveis séricos de $\lg G, \lg A$ e lgM foram comparados aos valores normais em crianças Brasileiras, em diferentes faixas etárias. Resultados: A resposta ao DNCB foi ausente ou fracamente reativa em $76 \%$ dos pacientes. Níveis séricos elevados de lgG $(45,7 \%)$ e de $\lg \mathrm{M}(61,4 \%)$ e baixos de $\lg \mathrm{A}(23,9 \%)$ foram detectados nos pacientes. A determinação das subpopulações de linfócitos $T$ em sangue periférico mostrou: deficiência nas proporções de células CD3+ $(p<0,05)$ e de $C D 4+(p<0,05)$, aumento de $C D 8+(p<0,01)$ e diminuição da relação CD4 / CD8 $(p<0,001)$. A proporção de células $C D 1+$ no grupo controle manteve-se menor que $3 \%$, enquanto que em $18 \%$ dos pacientes esses níveis variaram entre 3 e 11\%. A resposta proliferativa de linfócitos frente a PHA revelou índices blastogênicos significativamente mais baixos apenas quando células dos pacientes foram cultivadas na presença do próprio plasma (plasma autólogo). Quando estas células foram cultivadas na presença de plasma $A B$, não
\end{abstract} 'Professora Livre-Docente voluntária do Departamento de Neurologia e Psiquiatria, Faculdade de Medicina, Universidade Estadual Paulista,
Botucatu SP, Brasil (UNESP); 2Professora Adjunta Departamento de Microbiologia e Imunologia, Instituto de Biociências, UNESP.

Received 29 November 2002, received in final form 28 April 2003. Accepted 15 May 2003.

Dra. Terezinha C.B. Montelli - Department of Microbiology and Immunology, IB-UNESP - 18618-000 Botucatu SP - Brasil. E-mail: acmontelli@uol.com.br 
se evidenciou diferença significativa em relação ao grupo controle. Conclusão: A imunodeficiência na SW caracterizou-se por: anergia, alteração de imunidade mediada por células e dos níveis de imunoglobulinas, presença de timócitos imaturos na circulação periférica e deficiência funcional de linfócitos T induzida por fatores plasmáticos inibidores. Discutem-se as principais evidências de disfunção imune como imunodeficiência e autoimunidade.

PALAVRAS-CHAVE: dinitroclorobenzeno, síndrome de West, síndrome de Lennox-Gastaut, epilepsia com pontas multifocais independentes, células T, CD1, CD3, CD4, CD8, imunoglobulinas, resposta proliferativa de linfócitos.

West syndrome (WS) is an infantile epileptic encephalopathy, with a devastating clinical course characterized by axial spasms in clusters, hypsarrhythmia and psychomotor delay, beginning in the first year of life. Atypical presentation may include age of onset from the first month to 4 years, modified hypsarrhythmia, and psychomotor development ranging from normal to delayed or deteriorated. Were associated to WS multiple pathologies in Central Nervous System (CNS), such as structural anomalies, prematurity, phakomatoses, and CNS infections. But despite the multiple underlying factors, there are common clinical and electroencephalographic (EEG) patterns of WS that indicate a "final common pathway" for the pathophysiology of WS'. Ten to $20 \%$ of cases are considered idiopathic, with no evidence of brain lesions. According to the present knowledge about WS, spasms seem to involve subcortical structures, and hypsarrhythmia affects cortical areas, causing psychomotor deterioration ${ }^{2}$. Even though the pathogenesis is still unclear, a disturbance of immune function in the brain has been considered a possible factor ${ }^{1}$.

Infections are frequent and represent serious problems at times, leading to fatal outcome during ACTH treatment ${ }^{3}$. Infectious process have been involved in the etiology of WS, such as citomegalovirus, rubella and herpes simplex virus, meningococcus and pneumococcus ${ }^{4}$. Many cases of WS evolve with age into Lennox-Gastaut syndrome (LGS) ${ }^{5}$ or into multifocal independent spike syndrome (MIS) ${ }^{6}$.

Many clinical and experimental data strongly support the role of immune mechanisms in the pathogenesis of childhood epilepsy ${ }^{7,8}$. The role of immunity alterations is also clinically supported by the effectiveness of immunomodulatory treatments in children with catastrophic epilepsies ${ }^{9-11}$ and the spontaneous remission of the spasms after viral infections ${ }^{5,12}$. Our group previously reported immunological disturbances in patients with WS and LGS, consisting of impairment in T cell subclasses, $\mathrm{T}$ cell functional tests, in vivo skin sensitization tests and immunoglobulin levels and the demonstration of the presence of antibody to brain extract in the sera of WS and LGS children ${ }^{13-17}$. Other authors have described similar findings recently ${ }^{18-21}$.
The aim of this study was to assess the extent of immune dysfunction in WS, and in its evolutive and age-related disorders, LGS and MIS.

\section{METHOD}

Patients and controls - A group of 50 children, 23 males and 27 females, with the diagnosis of WS, LGS and MIS, followed at Hospital das Clínicas, Unesp, Botucatu, State University of São Paulo, was included in the study. Inclusion criteria were: 1 . they must have been followed in the outpatient clinic with the diagnosis of WS. The immunological study was performed at different points of the natural history of the disease, therefore we had included children with WS, LGS and MIS. 2. they must had had a regular follow-up, to permit a carefully prospective study. The longest follow-up lasted 17 years, and the shortest 11 months, with median age 2 years and 2 months; 3 . they must have had good nutritional condition. There were no selective procedures about characteristics of WS, LGS and MIS, neither frequency of infections.

Thirty-three patients with WS (median age 1y $3 \mathrm{mo}$, age ranges from 4 mo to $10 \mathrm{y} 2 \mathrm{mo}$ ), 10 with LGS (median age $8 \mathrm{y} 1 \mathrm{mo}$, age ranges from $3 \mathrm{y} 1 \mathrm{mo}$ to $18 \mathrm{y} 5 \mathrm{mo}$ ) and 7 with MS (median age 4y $1 \mathrm{mo}$, age ranges from $7 \mathrm{mo}$ to $15 y)$ were included in the study. The control group included 20 age-matched healthy children ( 12 males and 8 females).

Immunity was evaluated during infection-free periods, and ACTH-free therapy. Approval from Hospital Ethics Commission to study immunocompetence in children with convulsive disorders and informed consent from the parents of patients and controls were obtained.

Reagents - Monoclonal antibodies directed against human $\mathrm{CD} 1+, \mathrm{CD} 3+, \mathrm{CD} 4+$ and CD8+ were obtained from Ortho Diagnostics Systems, (Raritan, N.J.) and were employed throughout this study. For the indirect immunofluorescence assay, biotinylated horse anti-mouse IgG and fluorescein-labelled avidin-D (Vector Laboratories, Burlingame, PA) were used.

Enumeration of lymphocyte subsets - Peripheral blood mononulear cells were isolated from heparinized venous blood by Ficoll-Hypaque density centrifugation and resuspended in RPMI 1640 medium (Gibco Laboratories, Grand Island, N.Y.) supplemented with $10 \%(\mathrm{v}: \mathrm{v})$ of fetal calf serum. Approximately $2 \times 10^{5}$ cells were centrifuged onto a poly-l-lysine-coated coverslip and staining reactions carried out at $4^{\circ} \mathrm{C}$ as described previously ${ }^{22}$. Briefly, after reacting with the monoclonal antibody, the cells were treated with 
biotinylated horse anti-mouse IgG and fluoresceinated avidin-D and fixed in formaldehyde. At least 500 cells per sample were examined and scored under phase and fluorescence microscopy.

Proliferation assay - Lymphocyte cultures were prepared according to Musatti et al. ${ }^{23}$ Peripheral heparinized blood was obtained from patients and normal control subjects. After separation of mononuclear cells by Ficoll-Hypaque density centrifugation, the cells were washed twice in RPMI 1640 culture medium, and counted in a haemocytometer and cell viability was determined by $2 \%$ Trypan blue exclusion. The cell suspension was then diluted in RPMI 1640 medium to a final concentration of $2 \times 10^{6}$ cells $/ \mathrm{ml}$. One hundred microlitres of the cell suspension was cultivated separately in triplicate on flat-bottomed 96-well plates (Corning, Miami, FL, USA), and in the presence of RPMI medium containing $20 \%$ homologous AB or autologous heat-inactivated plasma. Control wells did not receive any stimulation and experimental wells were stimulated with $8 \mathrm{ug} / \mathrm{ml}$ PHA (Difco Laboratories, Detroit, $\mathrm{MI}$, USA). The cultures were incubated for $72 \mathrm{~h}$ in $5 \% \mathrm{CO}_{2}$ at $37^{\circ} \mathrm{C}$, and were pulsed with $1 \mathrm{mCi} / \mathrm{mM}$ Tritiated thymidine (specific activity $6.7 \mathrm{Ci} / \mathrm{mM}$; New England Nuclear, Boston, MA) $18 \mathrm{~h}$ before the end of incubation. The cells were harvested using an automatic collector (Cambridge Technology Inc., Cambridge, MA, USA). Isotope incorporation by the cell cultures was counted in a beta scintillation counter (Beckman Instruments, Inc., Los Angeles, CA, USA). The results are expressed as counts of radiation emission per minute (cpm) and defined as "blastogenic index" (BI) which is the ratio: $\mathrm{cpm}$ of stimulated tubes/cpm of control tubes. Based on the response of healthy controls, $\mathrm{BI}>20$ was considered as positive. The employment of $20 \%$ homologous $A B$ or autologous heat-inactivated plasma in lymphocyte cultures stimulated with PHA had the aim of detecting the presence of circulating immunosuppressive factors in plasma of patients and controls. The presence of inhibitory activity in the plasmas was determined by the suppression index (SI), obtained by the equation proposed by Park et al. $.^{24}: \mathrm{SI}=1-[\mathrm{cpm}$ cultures with PHA plus autologous plasma - cpm control cultures / cpm cultures with PHA plus homologous plasma - cpm control] x 100.
Immunoglobulins levels - Quantitative determination of $\lg G, \lg A$, and $\lg M$ were carried out by single radial immunodiffusion and the results expressed in $\mathrm{mg} / \mathrm{dl}$. Commercially prepared immunodiffusion plates with standards "Partigen plates" were purchased from Behringwerke, Marburg Laboratories (USA). The Ig values were compared to standard values for Brazilian population in different age ranges, as described by Naspitz ${ }^{25}$.

$D N C B$ test - Sensitization with dinitrochlorobenzene (DNCB) was accomplished according to Mendes et al. ${ }^{26}$. Sensitizing doses of $2000 \mathrm{ug}$ of DNCB dissolved in $0.1 \mathrm{~mL}$ of acetone were spread and maintained over a $2 \mathrm{~cm}$ area of skin, on the back skin of the patients for $48 \mathrm{~h}$. Eighteen or more days later, a patch test was repeated using 100 ug of DNCB in acetone, on a skin site different from the one used for sensitization. Skin reactions consisting of erythema and induration at $48 \mathrm{~h}$, were accepted as evidence of sensitization. This test was not performed in control healthy subjects due to ethical reasons.

Statistical analysis - Data were analyzed statistically using the INStat software (Graph Pad Software, San Diego, CA, USA). The results of T cell subsets from patients and control groups were analyzed by Student's $t$ test. Differences in the lymphocyte proliferative responses between patients and controls were compared by the non-parametric Mann-Whitney $U$ method, and blastogenic indices from lymphocytes cultured in the presence of autologous or homologous plasma in patients and control groups were analyzed by paired non-parametric Wilcoxon sign rank test. Significant values are considered to occur at $p<0.05$.

\section{RESULTS}

Forty children had secondary WS and 10 were included in the primary or criptogenic group. Infections were frequent in patients of both groups: 12 had meningitis, 20 had one or more episodes of pneumonia, 13 had recurrent mucocutaneous candidiasis and 10 had very frequent rhynopharingitis and otitis.

Table 1 shows the percentage of total T cells $(\mathrm{CD} 3+)$, helper inducer (CD4+), cytotoxic/suppressor $(\mathrm{CD} 8+) \mathrm{T}$-cell subsets and the CD4:CD8 ratio detected

Table 1. Percentages of $T$ cell subsets in patients and in healthy control group.

\begin{tabular}{cccc}
\hline $\mathrm{CD}+$ cell subsets & $\begin{array}{c}\text { Patients } \\
(\mathrm{n}=31)\end{array}$ & $\begin{array}{c}\text { Controls } \\
(\mathrm{n}=14)\end{array}$ & Significance* \\
\hline $\mathrm{CD} 3+$ & $53.3 \pm 12.9$ & $62.2 \pm 9.2$ & $\mathrm{p}<0.05$ \\
$\mathrm{CD} 4+$ & $32.5 \pm 11.6$ & $40.2 \pm 4.2$ & $\mathrm{p}<0.05$ \\
$\mathrm{CD} 8+$ & $31.7 \pm 12.6$ & $22.4 \pm 1.8$ & $\mathrm{p}<0.01$ \\
$\mathrm{CD} 4 / \mathrm{CD} 8$ & $1.16 \pm 0.1$ & $1.80 \pm 0.2$ & $\mathrm{p}<0.001$ \\
\hline
\end{tabular}


Table 2. Lymphocyte proliferative response to phytohemaglutinin in the presence of homologous and autologous plasma of patients and healthy controls.

\begin{tabular}{|c|c|c|c|}
\hline \multirow[t]{2}{*}{ Groups } & \multicolumn{2}{|c|}{ Blastogenic index } & \multirow{2}{*}{$\begin{array}{c}\text { Suppression index } \\
(\%)\end{array}$} \\
\hline & $\begin{array}{c}\text { Homologous } \\
\text { plasma }\end{array}$ & $\begin{array}{c}\text { Autologous } \\
\text { plasma }\end{array}$ & \\
\hline $\begin{array}{l}\text { Patients } \\
(\mathrm{n}=28)\end{array}$ & $\begin{array}{c}39.0 \\
(1.0-486.0)\end{array}$ & $\begin{array}{c}13.5^{+} \\
(1.0-246.0)\end{array}$ & $\begin{array}{c}46.3 \\
(0-97.7)\end{array}$ \\
\hline $\begin{array}{l}\text { Controls } \\
(n=20)\end{array}$ & $\begin{array}{c}36.0 \\
(25.0-66.0)\end{array}$ & $\begin{array}{c}34.5 \\
(20.0-60.0)\end{array}$ & $\begin{array}{c}1.9 \\
(0-35)\end{array}$ \\
\hline Significance \# & NS & $\mathrm{p}<0.01$ & $p<0.05$ \\
\hline
\end{tabular}

Results are expressed as median values of blastogenic index, and of suppression index, with the range in parentheses, * $\mathrm{SI}=1-[\mathrm{cpm}$ autologous plasma $-\mathrm{cpm}$ control / cpm homologous plasma - cpm control] $\times 100,{ }^{+}$autologous $x$ homologous plasma $-p<0.001$ (Wilcoxon test), " Mann-Whitney U test.

in peripheral blood of patients and healthy controls. A significant decrease in proportion of $\mathrm{CD} 3+, \mathrm{CD} 4+$ $T$ cells as well as an increase in the CD8+ cells were detected in the patients in comparison to the control group. Besides, a significant reduction in CD4:CD8 ratio was observed. In $81 \%(25 / 31)$ of the patients the CD4:CD8 values were below the mean \pm 2 SD of the value detected in the control group. An elevation of CD1 + cells was observed in some patients. While in the control group the proportion of CD1+ cells was less than $3 \%$, in $18 \%(4 / 22)$ of the patients these levels ranged between 6 and $11 \%$.

The in vitro lymphocyte proliferation assay in response to PHA was employed to evaluate the cellmediated immune response of patients with WS, LGS and MIS and the control group and the results were expressed as blastogenic index (Table 2). A significant impairment in the response to PHA, demonstrated by the low blastogenic indices was described, when the cells of the patients were cultivated in presence of their own plasma (autologous plasma), but not occurring in cultures with human $A B$ plasma (homologous plasma). The comparison between patients and controls by Mann-Whitney $U$ test revealed significant differences in relation to cell cultures in the presence of autologous plasma. No significant difference between patients and controls was detected when blastogenic indices were compared in cultures supplemented with homologous plasma. Based on the response of healthy controls, only 8 of 28 patients ( $28.7 \%$ ) exhibited blastogenic index bellow 20 (considered as positive).

Plasma from healthy controls had an inhibitory effect on T-cell proliferation assay with PHA ranging from 0 to $35 \%$, while this range was 0 to $97.7 \%$ in the patient group (Table 2). Thus, patient plasma with SI higher than $35 \%$ were considered as having an inhibitory effect on the cellular immune response to PHA. The median percentage of SI presented by the patients was significantly higher than that of controls. In 15 of 28 (53.6\%) patient plasmas, the presence of inhibitory effects was observed. These results suggest the presence of an inhibitory effect of the patient's plasma on their lymphocyte function.

Figures 1, 2 and 3 show respectively $\lg G, \lg A$ and IgM serum levels detected in the patients studied. The continuous line and the area between the broken lines represents the mean and the standard deviation of healthy control immunoglobulin values respectively, in accordance with standard values for Brazilian population in different age ranges, as described by

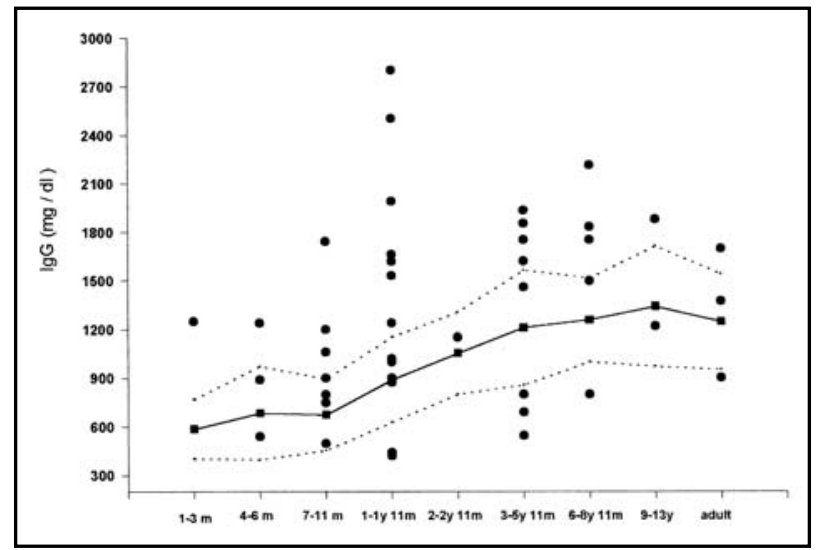

Fig 1. Serum levels of IgG in patients with West and Lennox syndromes and epilepsy with multifocal independent spikes with different ages. The continuous line and the shaded area represents respectively the mean and the normal range $( \pm S D)$ of the control healthy brazilian people, according to Naspitz, 1992 [25]. $m$, months; $y$, years. 


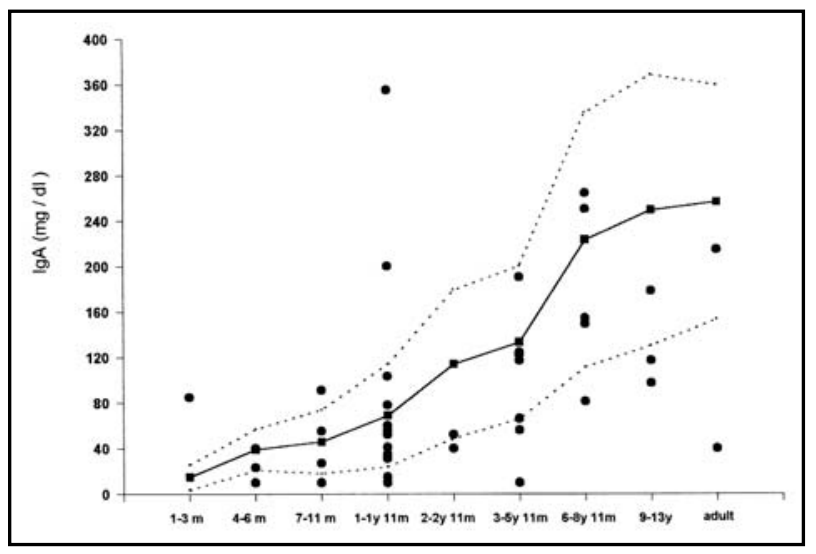

Fig 2. Serum levels of IgA in patients with West and Lennox syndromes and epilepsy with multifocal independent spikes with different ages. The continuous line and the shaded area represents respectively the mean and the normal range $( \pm S D)$ of the control healthy brazilian people, according to Naspitz, 1992 [25]. m, months; $y$, years.

Naspitz ${ }^{25}$. We observed few cases of depressed IgG $(15.2 \%=7 / 46)$ and $\operatorname{lgM}(2.1 \%=1 / 47)$ but more patients presented high levels of IgG $45.7 \%(21 / 46)$ and IgM $61.7 \%$ (29/47). On the other hand, 23,9\% $(11 / 46)$ of patients had lower levels of IgA and only $8.7 \%(4 / 46)$ showed values exceeding the upper normal range of controls in different age groups.

Skin reaction to DNCB were reduced in $76 \%$ of the patients. Erythema and induration occurred only in $24 \%(8 / 37)$ of the patients. Such low or absent skin sensitization could be considered as anergic responses.

\section{DISCUSSION}

This study demonstrated that patients with WS, LGS and MIS exhibited abnormalities in humoral and cell-mediated immune response. The analysis of $\mathrm{T}$ cell subsets showed significant decrease in proportion of $\mathrm{CD} 3+$ and $\mathrm{CD} 4+\mathrm{T}$ cells and an increase in CD8 + cells, leading to a consequent low CD4/CD8 ratio in more than $80 \%$ of the patients. These results confirm previous studies in epileptic patients, showing similar alterations in T cell subsets ${ }^{27}$. An initial deficiency of $B$ lymphocyte activity and a progressive dysfunction of $\mathrm{T}$ lymphocyte were reported in patients with epilepsy ${ }^{28}$. Other alterations such as impaired natural killer cell activity, low CD4+ and high CD8+ lymphocytes, reduction in the CD4+/CD8+ ratio, and decreased $\mathrm{C} 4$ complement were also described in epilepsy ${ }^{29}, 30$. Impairment in humoral immune response to antigens was reported in children with LGS ${ }^{21}$. All authors agree about the presence of a combined disorder of the immune and the nervous systems. Thus, evidence of an immune dysregulation

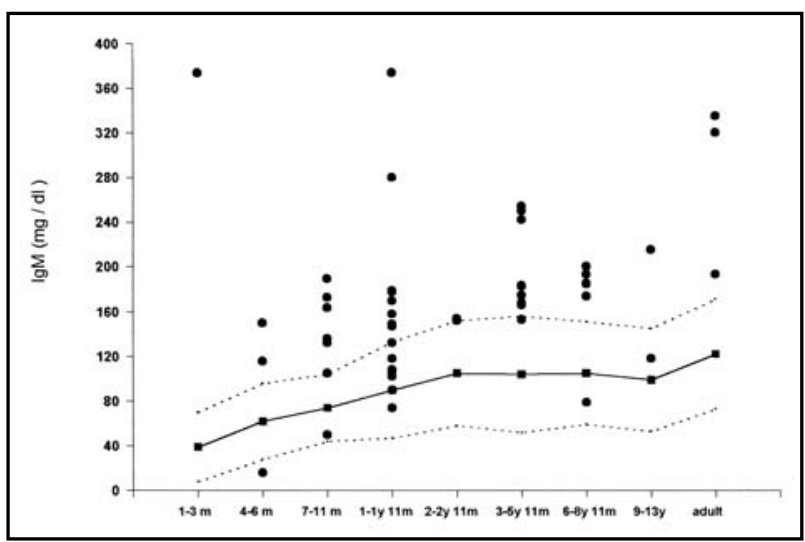

Fig 3. Serum levels of IgM in patients with West and Lennox syndromes and epilepsy with multifocal independent spikes with different ages. The continuous line and the shaded area represents respectively the mean and the normal range $( \pm S D)$ of the control healthy brazilian people, according to Naspitz, 1992 [25]. m, months; $y$, years.

associated with epilepsy has been regarded as being accounted for an increased prevalence of autoantibodies, and immunodeficiency.

In the present study it was also observed an elevation in proportion of CD1 + blood cells in $18 \%$ of the patients. The reason for the presence of these cells in the peripheral blood of the patients is unclear, since CD1 + cells are found in the thymic tissue as a cortical thymocyte antigens but not in peripheral blood from healthy individuals ${ }^{31,32}$. Significant increase of $C D 1+$ cells in the peripheral blood was detected in patients after acute marrow suppres$\operatorname{sion}^{33}$, in mothers of stillborn infants with neural tube defects $^{34}$, and in patients with acquired immunodeficiency syndrome ${ }^{35}$. The presence of thymocytes in the peripheral blood could be interpreted as the result of immature $T$ cells released to the periphery, and further studies are need for the clinical relevance knowledge of this finding. The results of lymphocyte proliferation in response to PHA stimulus showed a significant impairment of cell-mediated immunity when lymphocytes of patients were stimulated in vitro with the mitogen, in the presence of their own plasma, as detected by the low blastogenic index. These results as well as the reports obtained in other pathologies such as, febrile seizures $^{36}$ and infectious diseases ${ }^{23,37}$ are compatible with the presence of inhibitory factors in patient plasma. The nature of these inhibitory factors has not been clarified yet, but some evidence indicate that antibodies, immune complexes, serum protein as alpha2-macroglobulin and parasite antigens may 
exert in vitro an immunosupressive effect ${ }^{37-40}$. Autoantibodies against brain cell-antigens were detected in epileptic patients ${ }^{41-43}$ and in children with WS and LGS ${ }^{16}$. Since it was not observed the inhibitory activity on lymphocyte proliferative response in our patients when their cells were cultivated in the presence of $A B$ plasma, it is possible that antibodies to brain tissue, present in autologous plasma, might play an inhibitory role on the cell-mediated immune response in vivo. This effect could be related to the immunodeficiency observed in patients with WS, LGS, and MIS.

Low or absent skin sensitization to DNCB was observed in patients with WS, LGS and MIS. Skin reactions were detected only in $24 \%$ (8/37) of the patients. This may be interpreted as an inability of these children in developing an immune response to newly encountered antigens, as previously suggested in patients with selective IgA deficiency ${ }^{44}$. DNCB sensitization has been reported as positive in $87 \%$ of normal children of 1-5 years of age ${ }^{45}$ and in $92 \%$ of children aged between 1 - 17 years ${ }^{46}$. In previous papers we detected anergy to DNCB in children with WS and LGS ${ }^{13,14}$. This anergy might be related to decreased ability to mount an inflammatory response or to any basic immunological defect.

We detected high levels of IgG and IgM in $45.7 \%$ and $61.7 \%$ of the patients, respectively, while the levels of IgA were low in the serum of $23.9 \%$ of the patients with WS, LGS and MIS. Although the patients did not presented any infection at the time of the immunity evaluation, the elevated levels of IgG and IgM might be associated to the past frequent episodes of infections in these children. On the other hand it is possible that some of these immunoglobulins might represent an immune response against brain tissue, as described in our previous study ${ }^{13,16}$. High concentration of serum IgG and IgM in children with WS, LGS and other forms of epilepsy were reported by other authors ${ }^{30,47}$. Low IgA levels were found in 5 of 12 patients with myoclonic epilepsy by Nieto et al. ${ }^{48}$. Eriksson et al. ${ }^{9}$. also referred low IgA levels in up to $25 \%$ of epileptic patients. Hrachovy et al. ${ }^{18}$ concluded that $B$ cells were increased in number and activated in a study of 7 patients with WS.

Our group related the presence of precipitating antibodies to a saline extract of brain tissue in the sera of 24 children with WS and LGS ${ }^{16}$. This finding was later confirmed by increasing the number of patients studied ${ }^{13}$. Several authors also referred the presence of autoantibodies to brain-cell-antigens in epi- leptic patients ${ }^{9,11,41-43,49-53}$. There were described self antibodies to glial brain specific proteins of the group S-100 and undifferentiated proteins ${ }^{51}$, IgG subunits to cerebrocyte antigens of human embrio ${ }^{43}$, acetylcholine receptor and anti-synaptic membrane antibodies $^{52}$, anti-GM1 ganglioside antibodies ${ }^{41}$, antibodies to proteins $\mathrm{p} 16, \mathrm{p} 30$ and $\mathrm{S}-100^{54}$, to glutamate receptor subunits ${ }^{49}$, to phospholipids ${ }^{9,42}$, and cardiolipin ${ }^{53}$.

Experimental epilepsy studies with anti-brain antibodies demonstrated that epileptiform discharges can be obtained with anti-neural $\operatorname{lgG}^{55}$, antiserum to the synaptic membrane fraction ${ }^{56}$, and to brain ganglioside $\mathrm{GM} 11^{57-59}$. The demonstration of autoantibodies to GluR3 in Rasmussen encephalitis, that have agonist properties at the receptor, provides a pathogenic model for hyperexcitability leading to epilepsy ${ }^{60,61}$. On the other hand, there are examples of autoantibody production without autoimmune disease $^{60,62}$. Such responses are not always harmful and had an important role in regulating the immune response ${ }^{62,63}$. In a remarkable study, During et al. ${ }^{64}$. reported that a vaccine to an adeno-associated virus generated autoantibodies that targeted a specific brain protein, the NR1 subunit of the N-methyl-Daspartate receptor. These autoantibodies had strong anti-epileptic activity. However, to stablish that a disease has an autoimmune etiology, it is necessary to demonstrate the autoantibody or cell-mediated immunity, the corresponding antigen must be identified, the autoimmune response be obtained in experimental animals and a similar disease must develop. Finally, the direct transfer of autoantibodies or sensitized cells must induce the disease in animals. These conditions were only accomplished with Rasmussen encephalitis ${ }^{65}$.

Concluding, the immunodeficiency in WS was mainly characterized by disturbances of cell-mediated immunity and in the levels of immunoglobulins, anergy, presence of immature thymocytes in peripheral blood and functional impairment of $T$ lymphocytes induced by inhibitory plasma factors. These findings must have implications in medical care of patients, in order to prevent and treat infections.

The immune mechanisms involved in the pathophysiology of these epileptic syndromes could be better understood by determination of cytokine patterns produced by lymphocytes. Immunomodulatory treatment may improve the course of the disease and perhaps become the next aspect to be seriously investigated. 


\section{REFERENCES}

1. Zhi-Sheng Liu, Qin-Wen Wang, Fang-Lin Wang, Li-Zhi Yang. Serum cytokine levels are altered in patients with West syndrome. Brain Dev 2001;23:548-551.

2. Dulac O. What is West Syndrome? Brain Dev 2001;23:447-452.

3. Shamir R, Garty BZ, Rachmel A, Kivity S, Alpert G. Risk of infection during adrenocorticotropic hormone treatment in infants with infantile spasms. Pediatr Infect Dis 1993;12:913-916.

4. Riikonen R. Infantile spasms: infectious disorders. Neuropediatrics 1993;24:274-280

5. Lombroso CT. A prospective study of infantile spasms: clinical and therapeutic correlations. Epilepsia 1983;24:135-158.

6. Noriega-Sanchez A, MarkandON. Clinical and electroencephalographic correlation of independent multifocal spike discharges. Neurology 1976;26:667-72.

7. Benson M, Blennow G, Rosen I. Intrathecal immunoglobulin production and minor motor seizures. Acta Paediatr Scand 1987;76:147-150.

8. Duse M, Notarangelo LD, Tiberti S, Menegati E, Plebani A, Ugazio AG Intravenous immune globulin in the treatment of intractable childhood epilepsy. Clin Exp Immunol 1996;104:71-76.

9. Eriksson K, Peltola J, Keranen T, Haapala AM, Koivikko M. High prevalence of antiphospholipid antibodies in children with epilepsy: a controlled study of 50 cases. Epilepsy Res 2001;46:129-137.

10. Lousa M, Sanchez-Alonso S, Rodriguez-Diaz R, Dalmau J. Status epilepticus with neuron-reactive serum antibodies: response to plasma exchange. Neurology 2000;54:2163-2165.

11. Wiendl H, Bien CG, Bemasconi P, et al. Glu R3 antibodies: prevalence in focal epilepsy but no specificity for Rasmussen's encephalitis. Neurology 2001;57:1511-1514.

12. Hattori H. Spontaneous remission of spasms in West syndrome. Implications of viral infections. Brain Dev 2001;23:705-707.

13. Montelli TCB. Síndrome de West, Lennox-Gastaut e epilepsia com descargas multifocais independentes: imunodeficiência e hipótese de autoimunidade. Thesis. Botucatu, 1995.

14. Montelli TCB, Mota NGS, Peraçoli MTS, Torres EA, Rezkallah-Iwasso MT. Immunological disturbances in West and Lennox-Gastaut syndromes. Arq Neuropsiquiatr 1984;42:132-139.

15. Montelli TCB, Peraçoli MTS, Soares AMVC, et al. Sensibilidade mutagênica, atividade de células natural killer e distribuição de subpopulações de linfócitos T em pacientes com síndrome de West. Resultados preliminares. Arq Neuropsiquiatr 1992;50:115.

16. Mota NGS, Rezkallah-Iwasso MT, Peraçoli MTS, Montelli TCB. Demonstration of antibody and cellular immune response to brain extract in West and Lennox-Gastaut syndromes. Arq Neuropsiquiatr 1984;42:126-131.

17. Montelli TCB, Rezkallah-Iwasso MT, PeraçoliMTS, Mota NGS. Immunologic disturbance in West and Lennox-Gastaut syndromes and in epilepsy with independent multifocal spikes. Cleveland Clin J Med 1989;56:S-285.

18. Hrachovy RA, Frost JD, Shearer JL, et al. Immunological evaluation of patients with infantile spasms. Ann Neurol, 1985;18:414.

19. Illum N, Taudorf K, Heilmann C, et al., Intravenous immunoglobulin: a single-blind trial in children with Lennox-Gastaut syndrome. Neuropediatrics 1990;21:87-90.

20. Plioplys AV, Greaves A, Yoshida W. Anti-CNS antibodies in childhood neurologic diseases. Neuropediatrics 1989;20:93-102.

21. Van Engelen BG, Weemaes CM, Renier WO, Bakkeren JA, Borm GF, Strengers PF. A dysbalanced immune system in cryptogenic LennoxGastaut syndrome. Scand J Immunol 1995;41:209-213.

22. Van Voorhis WC, Hair LS, Steinman RM, Kaplan G. Human dendritic cells. Enrichment and characterization from peripheral blood. J Exp Med 1980;155:1172-1187

23. Musatti CC, Rezkallah MT, Mendes E, Mendes NF. In vivo and in vitro evaluation of cell-mediated immunity in patients with paracoccidioidomycosis. Cell Immunol 1976;24:365-378.

24. Park MI, Edwin SS, Scott JR, Branch DW. Interpretation of blocking activity in maternal serum depends on the equation used for calculation of mixed lymphocyte culture results. Clin Exp Immunol 1990;82:363-368.

25. Naspitz CK. Mecanismos básicos da resposta imunológica. In Melaragno R Filho R, Nasptiz CK. (eds). Neuroimunologia, São Paulo Sarvier, 1982:11-35.

26. Mendes E, Raphael A, Mota NGS, Mendes NF. Cell-mediated immunity in leprosy and transfer of delayed hypersensititvity reactions. J Allergy Clin Immunol 1971;53:233-239.

27. Eeg-Olofsson O, Osterland CK, Guttmann RD, et al. Immunological studies in focal epilepsy. Acta Neurol Scand 1988;78:358-368.

28. Shmatko VG, Kvetkova EA, Ereniev SI. Clinico-immunologic correlations in epilepsy. Zh Nevropatol Psikiatr Im S S Korsakova, 1984;84:814-819.

29. Margaretten NC, Warren RP. Reduced natural killer cell activity and OKT4/OKT8 ratio in epileptic patients. Immunol Invest 1986;15:159-167.

30. Bostantjsopoulou S, Hatzizisi O, Argyropoulou O, et al. Immunological parameters in patients with epilepsy. Funct Neurol 1994;9:11-15.

31. Bradstock KF, Kerr A, Grimsley P, Kirk J, Luxford C. Phenotypic characterization of immature lymphoid cells in human umbilical cord blood. Immunol Cell Biol 1988;66:387-394.

32. Sotzik F, Boyd A, Shortman K. Surface antigens of human thymocyte populations defined by CD3, CD4 and CD8 expression: CD1a is expressed by mature thymocytes but not peripheral T Cells. Immunol Lett 1993;36:101-106.

33. Caldwell CW, Poje E, Cooperstock M. Expansion of immature thymic precursor cells in peripheral blood after acute marrow suppression. Am J Clin Pathol 1991;95:824-827.
34. Seniz FN, Muftuoglu E, Batun MS, Say B. CD1+ cells in mothers of stillborn infants with neural tube defects. Am J Med Genet 1995;56:60-61.

35. Chollet-MartinS,PialouxG, Gougerot-PocidaloMA. Increased CD1-positivecells in peripheral blood of AIDS and ARC patients. Immunol Lett 1988;17:53-57.

36. Montelli TCB, Soares AMVC, Parise-Fortes MR, Rezkallah-Iwasso MT, Padula NMR, Peraçoli MTS. Alterations of cell-mediated immune response in children with febrile seizures. Arq Neuropsiquiatr 1997;55:193-198.

37. Sugizaki MF, Peraçoli MTS, Mendes-Giannini MJS, et al. Correlation between antigenemia of Paracoccidioides brasiliensis and inhibiting effects of plasma in patients with paracocidioidomycosis. Med Myco 1999;37:277-284.

38. Chequer-Bou-Habib D, Oliveira-Neto MP, Ferreira-da-Cruz MF, GalvãoCastro B. The possible role of circulating immune complexes in the deficiency of cell-mediated immunity in paracoccidioidomycosis. Braz J Med Biol Res 1989;22:205-212.

39. Horwitz DA, Garret MA, Craig AH. Serum effects on mitogenic reactivity in subjects with systemic lupus erythematosus, rheumatoid arthritis and scleroderma: technical considerations and lack correlation with antilymphocyte antibodies. Clin Exp Immunol 1977;27:100-110.

40. Riely GJ, Rachmilewitz J, Koo PH, Tykocinski ML. Alpha2-macroglobulin modulates the immunoregulatory function of the lipocalin placental protein 14. Biochem J 2000;3512:503-508.

41. Bartolomei F, Boucraut J, Barrie M, et al. Cryptogenic partial epilepsies with anti-GM1 antibodies: a new form of immune-mediated epilepsy? Epilepsia 1996;37:922-926.

42. Peltola JT, Haapala A, Isojarvi JI, et al., Antiphospholipid and antinuclear antibodies in patients with epilepsy or new-onset seizure disorders. Am J Med 2000;109:712-717.

43. Xie XK, Tang LO. Observation on anti-brain antibody in serum of 110 epileptics, Chin Med J 1990;103:71-75.

44. De Graeff PA, The TH, Van Munster PJ, Out TA, Vossen JM, Zegers BJ The primary immune response in patients with selective IgA deficiency. Clin Exp Immunol 1983;54:778-784.

45. Sanjeev Rai B, Krishnamurthy PN, Rama Rao BR. Study of cell-mediated immunity in malnourished children with DNCB skin sensitization test Indian Pediatr 1981;18:29-33.

46. Ryniewicz B, Pawinska M. Preliminary immunological studies in spinal muscular atrophy. Eur J Pediatr 1978;128:57-60.

47. Haraldsson A, van Engelen BG, Renier WO, Bakkeren JA, Weemaes CM. Light chain ratios and concentrations of serum immunoglobulins in children with epilepsy. Epilepsy Res 1992;13:255-260.

48. Nieto M, Roldan S, Sanchez B, Candau R, Rodriguez R. Immunological study in patients with severe myoclonic epilepsy in childhood. Rev Neurol 2000;30:412-414

49. Dambinova SA, Izykenova GA, Burov SV, Grigarenko EV, Gromov SA, The presence of autoantibodies to N-terminus domain Glu R1 subunit of AMPA receptor in the blood serum of patients with epilepsy. J Neurol Sci 1997;152:93-97.

50. Mukharinskaia VS, Antadze ZI, Kipiani MK, Vashklevich RI, Arutiunova ES. State of humoral immunity in epilepsy patients (abs). Zh Nevropatol Psikhiatr Im SS Korsakova1980;80:1074-1077.

51. Poletaev AB, Karlov VA, Pomogaeva MV, Selifanova OP, Immunoenzyme analysis of the antigenic orientation of anti-brain autoantibodies in the serum of epileptics. Zh Nevropatol Psikhiatr Im S S Korsakova 1985;85:831-833.

52. Qu ZP, Yy LY, Lu CZ, Quiao J, Lin YX, Hong Z. A preliminary observation on auto-cholinergic synapse dysfunction in patients with different types of epilepsy. Jpn J Psychiatry Neurol 1992;46:401-403.

53. Yoshimura K, Konishi T, Kotani H, Wakiguchi H, Kurashige T. Prevalence of positive anticardiolipin antibody in benign infantile convulsion. Brain Dev 2001;23:317-320.

54. Morozov SG, Gnedenko BB, Asanova LM, Abramova OS. Autoantibodies to brain tissue antigens in epilepsy patients. Zh Nevropatol Psikhiatr Im S S Korsakova 1996;96:71-74.

55. Vlajkovic S, Jankovic BD. Experimental epilepsy in vitro: neuromodulating activity of anti-brain autoantibodies from rats exposed to electroconvulsive shock. Int J Neurosci 1991;59:205-211.

56. Karpiak SE, Serokosz M, Rapport MM. Effects of antisera to S-100 protein and to synaptic membrane fraction on maze performance and EEG. Brain Res 1976;102:313-321.

57. Karpiak SE, Graf L, Rapport MM. Antiserum to brain gangliosides produces recurrent epileptiform activity. Science 1976;194:735-737.

58. Karpiak SE, Huang YL, Rapport MM. Immunological model of epilepsy. Epileptiform activity induced by fragments of antibody to GM1 ganglioside. J Neuroimmunol 1982;3:15-21.

59. Karpiak SE, Mahadik SP, Graf L, Rapport MM An immunological model of epilepsy: seizures induced by antibodies to GM1 gangliosides. Epilepsia 1981;22:189-196.

60. Barinaga M. Antibodies linked to rare epilepsy. Science 1995;268:362-363.

61. Rogers SW, Andrews PI, Gahring LC, et al. Autoantibodies to glutamate receptor Glu R3 in Rasmussen's encephalitis. Science 1994;265:648-651.

62. Rees AJ. Autoimmunity and autoimmune disease. Brit J Anesthesiol 1979:51:13-20.

63. Jerne NK. The immune system. Sci Am 1973;229:52-60.

64. During MJ, Symes CW, Lawlor PA, et al. An oral vaccine against NMDAR1 with efficacy in experimental stroke and epilepsy. Science 2000;287:1453-1460.

65. Aarli JA. Epilepsy and the immune system. Arch Neurol 2000;57:1689-1692. 